\title{
Inactivating SETD2 Gene Mutation
}

National Cancer Institute

\section{Source}

National Cancer Institute. Inactivating SETD2 Gene Mutation. NCI Thesaurus. Code C156048.

A change in the nucleotide sequence of the SETD2 gene that inhibits expression or results in the translation of either low-activity or inactive forms of the histone-lysine methyltransferase SETD2 protein. 